\title{
Pentingnya Komunikasi dalam Penafsiran Alkitab
}

\author{
Lyly Grace Mantiri \\ Sekolah Tinggi Teologi Huperetes, Batam, Kepulauan Riau \\ lyly_grace@stth.ac.id
}

\begin{abstract}
This article will discuss a theological correlation between communication and biblical interpretation. After having established that coherence, it will show that the Reader-Response Criticism, one of the most attractive approach in Biblical interpretation among the postmodern scholars, is not only irrational but also dangerous to some degree even inapplicable and without spiritual value.
\end{abstract}

Keywords: communication; biblical interpretation; reader response-criticism; text

\begin{abstract}
Abstrak: Artikel ini membahas hubungan teologis antara komunikasi dan penafsiran Alkitab. Setelah menemukan hubungan antara kedua hal tesebut, artikel ini akan menelaah secara khusus mengenai Kritik Respons-pembaca, salah satu pendekatan paling menarik dalam penafsiran Alkitab di antara para sarjana postmodern, Artikel ini akan memperlihatkan bahwa metode ini tidak hanya irasional tetapi juga berbahaya sampai taraf tertentu, bahkan tidak dapat diterapkan dan tanpa nilai spiritual.
\end{abstract}

Kata Kunci: komunikasi; kritik respon pembaca; penafsiran Alkitab; teks Alkitab

\begin{tabular}{llll}
\hline Article History : & Received: 04-02-2018 & Revised: 06-03-2018 & Accepted: 22-03-2019
\end{tabular}

\section{Pendahuluan}

Komunikasi adalah proses transfer informasi atau pesan dari satu pihak kepada pihak lain. Berdasarkan cara transfer pesan atau informasi, para teoris komunikasi membagi komunikasi ke dalam sejumlah model, yaitu: gestural (komunikasi yang berbasis gerakan tangan), vokal (komunikasi berbasis suara), visual (komunikasi menggunakan gambar), signal (komunikasi berbasis gerakan tubuh). ${ }^{1}$ Terlepas dari beragam mode komunikasi tersebut, dapat dipastikan bahwa komunikasi yang bermakna penuh hanya dapat dilakukan oleh makluk berpribadi (manusia). Komunikasi terjadi secara personal, yaitu bahwa yang memiliki kapasitas dan kemampuan untuk melakukan komunikasi adalah makhluk berpribadi (Allah, makhluk-makhluk spiritual, dan manusia).

Pada domain kehidupan manusia di dalam segala aspeknya, komunikasi merupakan salah satu dari aktivitas-aktivitas terpenting yang bukan hanya menandai

${ }^{1}$ Marcel Danesi, Dictionary of Media and Communications (New York, London: M.E. Sharpe, 2009), 
karakteristiknya sebagai makhluk berpribadi melainkan juga penting dalam hampir semua tingkat relasinya baik dengan dirinya sendiri, dengan sesama, termasuk dengan Tuhan. Danny McCain dan Craig S. Keener menyatakan,

Komunikasi adalah salah satu dari aktivitas-aktivitas paling penting kita sebagai manusia yang kita lakukan setiap hari. Allah telah menciptakan kita sebagai ciptaan-ciptaan yang secara teratur dan terus-menerus melakukan dan menafsirkan komunikasi. ${ }^{2}$

Artikel ini dimaksudkan untuk membahas tentang hubungan teologis antara penafsiran Alkitab dan komunikasi. Salah satu alasan utama mengapa isu ini penting adalah mayoritas buku-buku pegangan hermeneutik Alkitab dalam bahasa Indonesia maupun dalam bahasa Inggris mengabaikan begitu saja isu ini. Padahal, pada naturnya, baik pewahyuan (revelation) maupun proses penafsiran merupakan kategori tidak terpisahkan dari proses komunikasi. ${ }^{3}$

Dengan demikian, artikel ini dapat memberikan suplemen penting untuk pemahaman yang lebih komprehensif akan dimensi komunikasi dalam tugas penafsiran Alkitab. Bukan hanya itu, penelitian ini secara khusus untuk membedah rasionalitas sebuah pendekatan tafsir Postmodern bernama Kritik Respon-Pembaca. Tujuanmya adalah membuktikan bahwa skema dari pendekatan ini justru memimpin kepada implikasiimplikasi yang absurd.

\section{Wahyu Umum dan Khusus}

Dalam terang Monotheism Unitarian (atau Monotheisme Solitarian), komunikasi tidak dapat dianggap sebagai atribut kekal Allah karena di dalam kekekalan yang lampau, sebelum adanya penciptaan, Allah itu tunggal baik dalam Pribadi maupun Esensinya. Komunikasi tidak memiliki peluang di dalam skema teologi Ketuhanan semacamini sebab komunikasi mengasumsikan pihak lain sebagai recipient (penerima) dari message (pesan) yang merupakan bagian tidak terpisahkan dari komunikasi.

Tetapi, dalam doktrin Ketuhanan Kristen yang ortodoks, Allah Tritunggal-Tiga Pribadi Satu Esensi-yakni bahwa Bapa, Anak, dan Roh Kudus berkomunikasi dalam keharmonisan dan kesempurnaan. Dalam kategori Tritunggal, komunikasi merupakan atribut kekal dari Allah sendiri. Relasi kekal antar-Pribadi Allah Tritunggal mengharuskan kesimpulan bahwa komunikasi merupakan atribut kekal Allah. Allah Tritunggal tidak memerlukan ciptaan untuk dapat berkomunikasi. Pandangan komunikasi merupakan atribut kekal Allah (God as communication being) bukan merupakan pandangan esoteric penulis sendiri, meskipun harus diakui bahwa tidak banyak karya-karya teologi sistematika Kristen yang menegaskan proposisi ini. Namun seorang teolog besar,

2Danny McCain and Craic S. Keener, Understanding and Applying the Scripture (Epub version; Plauteau State: Africa Christian Textbook, 2012), 256.

${ }^{3}$ Grant R. Osborne, The Hermeneutical Spiral: A Comprehensive Introduction to Biblical Interpretation (Downers Grove, Illinois: IVP Academic, 2006), 
Jonathan Edwards mendeklarasikan, "Allah adalah sebuah keberadaan yang berkomunikasi," dan bahwa "hal yang ingin dicapai Allah dalam penciptaan dunia...adalah untuk mengomunikasikan diri-Nya."4

Dalam terang kategori atribut Allah yang communicable dan incomunnicable, kemampuan untuk berkomunikasi merupakan bagian dari pengertian bahwa manusia diciptakan menurut gambar dan rupa Allah. Manusia memiliki keinginan dan kemampuan untuk berkomunikasi karena manusia diciptakan oleh Allah sendiri yang juga adalah keberadaan yang berkomunikasi (communication being).

Seperti yang dinyatakan oleh Edwards di atas, Allah yang adalah keberadaan yang berkomunikasi itu berinisiatif mengkomunikasikan diri-Nya, secara khusus, dengan manusia melalui pewahyuan (revelation). 5 Dalam hal ini, teologi Kristen mengenal dua kategori pewahyuan yaitu pewahyuan umum (general revelation) dan pewahyuan khusus (special revelation). Profesor John M. Frame menyatakan bahwa dalam kedua kategori pewahyuan ini, Allah menyingkapkan dirinya melalui tiga media spesifik, yaitu peristiwa-peristiwa, pribadi-pribadi, dan kata-kata. ${ }^{6}$

Dalam kategori pewahyuan umum, Allah mengomunikasikan Diri dan kehendakNya melalui alam semesta yang Ia ciptakan dan melalui hati nurani manusia. Melalui alam semesta, manusia dapat melihat dan mengetahui bahwa Allah adalah Pencipta segala sesuatu. Perhatikan apa yang diungkapkan dalam Mazmur19:1-6, "Langit menceritakan kemuliaan Allah, dan cakrawala memberitakan pekerjaan tangan-Nya... Tidak ada berita dan tidak ada kata, suara mereka tidak terdengar; tetapi gema mereka terpencar ke seluruh dunia, dan perkataan mereka sampai ke ujung bumi..." Tremper Longman menyatakan bahwa Mazmur 19 merupakan sebuah "thoughtful dan powerful reflection upon God's self-disclosure to humanity." 7 Komentar Longman tepat karena dalam Mazmur 19, Daud menggunakan ungkapan-ungkapan puitis untuk menyatakan kemuliaan Allah, yaitu Allah di dalam segala kebesaran dan keagungan-Nya dapat dilihat melalui karya penciptaan yang dilakukan-Nya yaitu segenap jagad raya. Demikian juga yang diungkapkan Daud dalam Mazmur 98:1-2, di mana umat Israel dipanggil untuk menyanyikan nyanyian baru karena Allah memperlihatkan kepada bangsabangsa keselamatan dan keadilan-Nya melalui perbuatan-perbuatan-Nya yang ajaib yang dapat dilihat dan disaksikan oleh mereka (bnd. Mzm. 33:3; 40:3; 96:1; 144:9; 149:1). ${ }^{8}$

\footnotetext{
${ }^{4}$ Dikutipdalam: Michael J. McClymond and Gerald R. McDermott, The Theology of Jonathan Edwards (Epub version; New York: Oxford University Press, 2012), loc., 99/544.

${ }^{5}$ Lih. McClymond and Gerald R. McDermott, The Theology of Jonathan Edwards, loc., 99/544.

${ }^{6} J o h n$ M. Frame, Systematic Theology: An Introduction to Christian Belief (Epub version; Phillipsburg, New Jersey: P\&R, 2013), loc., 411-429/1107.

${ }^{7}$ Tremper Longman, Psalms (Epub version; TOTC Vols. 15-16; Downers Grove, Illinois:IVP, 2014), loc., $82 / 362$.

8Ibid., 252/362.
} 
Allah juga menaruh benih-benih pengenalan dan kerinduan akan Dia di dalam diri manusia, yakni di dalam hati nurani manusia, yang disebut oleh Bapa-bapa Gereja maupun oleh John Calvin dengan sebutan sensus divinitatis atau sensus deitatis (benih keilahian)atau semen religionis (benih agama). ${ }^{9}$ Benih keilahian ini diberikan kepada semua orang, menjadi kesaksian internal dalam diri manusia mengenai Tuhan dan kekekalan, sebagaimana yang terdapat dalam Pengkhotbah 3:11, "Ia membuat segala sesuatu indah pada waktunya, bahkan Ia memberikan kekekalan dalam hati mereka. Tetapi manusia tidak dapat menyelami pekerjaan yang dilakukan Allah dari awal sampai akhir."

Tuhan juga mengomunikasikan diri-Nya melalui wahyu khusus, yaitu Yesus Kristus dan Alkitab. Penulis Surat Ibrani menyatakan:

Setelah pada zaman dahulu Allah berulang kali dan dalam pelbagai cara berbicara kepada nenek moyang kita dengan perantaraan nabi-nabi, maka pada zaman akhir ini Ia telah berbicara kepada kita dengan perantaraan Anak-Nya, yang telah Ia tetapkan sebagai yang berhak menerima segala yang ada. Oleh Dia Allah telah menjadikan alam semesta (Ibr. 1:1-2).

Menurut bagian di atas, sebelumnya Allah telah berkomunikasi dengan manusia dengan menggunakan berbagai sarana, namun pada jaman akhir ini Ia berbicara melalui AnakNya, Yesus Kristus. Itulah sebabnya, Herman Bavinck - seorang teolog Reformed asal Belanda - menyatakan, "Semua pewahyuan - umum dan khusus - akhirnya mencapai klimaks dan maknanya di dalam Kristus."10

Memang, Kristus sendiri juga mengajarkan bahwa pewahyuan yang dilakukan Allah sejak jaman para nabi bersifat Christotelic (tujuan atau klimaksnya adalah Kristus). Hal ini dinyatakan-Nya setelah kebangkitan-Nya, khususnya ketika Ia menampakan diriNya kepada dua orang yang berjalan ke Emaus. Kristus menegor kelambanan mereka untuk mengenal Dia (Luk. 24:25-27). Kristus bukan hanya menandaskan bahwa Ia adalah klimaks dari inisiatif dan tindakan komunikasi Allah, melainkan juga bahwa inisiatif dan tindakan komunikasi Allah itu bertujuan redemptif, yaitu penebusan manusia yang berdosa melalui penyaliban dan kebangkitan-Nya.

Jadi, Allah adalah Allah yang berkomunikasi, sekalipun Ia infinit dan personal, Dia tetap menjangkau manusia yang finit dan personal melalui wahyu-wahyu-Nya. Francis A. Schaeffer menyatakan,

Kita dapat mengatakannya dengan cara lain, dan itu adalah bahwa Allah Pribadi yang tidak terbatas, Allah yang adalah Trinitas, telah berbicara. Ia ada dan Ia tidak bisu. Tidak ada gunanya memiliki Allah yang bisu. Kita tidak akan mengetahui apapun tentang Dia. Dia telah berbicara dan memberitahu kita apa Dia dan bahwa Dia ada sebelum segala sesuatu ada, dan karena itu kita memiliki jawaban tentang

"Lih. Paul Helm, "John Calvin: The Sensus Divinitatis and the Noetics Effects of Sin," International Journal for Philosophy of Religion, 43/2 (1988): 87-107.

${ }^{10}$ Herman Bavinck, Reformed Dogmatics: Vol One - Prolegomena, trans. John Vriend (Epub version; Grand Rapids, Michigan: Eerdmans, 2003), loc., 222/510. 
keberadaan-Nya. Allah tidak diam....Allah Trinitas tidak diam. Ia memberitahu kita siapa Dia. 11

Ia bukan hanya menciptakan manusia sebagai makhluk yang berkomunikasi, melainkan juga Ia mengambil inisiatif untuk berkomunikasi dengan manusia melalui wahyu umum dan wahyu khusus. Klimaks dari tindakan komunikasi Allah dalam seluruh tindakan pewahyuan-Nya adalah Kristus dan tujuannya adalah penebusan demi kemuliaan nama-Nya (Rm. 11:36). ${ }^{12}$ Komunikasi di dalam Alkitab berlangsung dalam sebuah skemabesar (grand design) rencana penebusan bagi umat-Nya. ${ }^{13}$

\section{Metode Penelitian}

Artikel ini merupakan sebuah penelitian kualitatif dengan kajian literatur atas persoalan penafsiran Alkitab. Metode yang digunakan adalah deskriptif dan analisis historis. Metode deskriptif digunakan untuk memberikan gambaran tentang beberapa teori yang berkembang dalam penafsiran Alkitab.

\section{Penafsiran Alkitab}

Seperti yang sudah dikemukakan di atas, tindakan komunikasi itu tercakup di dalamnya tindakan menafsirkan komunikasi. Juga sudah dikemukakan bahwa Alkitab merupakan bukti tindakan komunikasi Allah untuk menyingkapkan diri dan kehendak-Nya. Maksud Allah melalui pewahyuan Diri-Nya dalam Alkitab harus menjadi tujuan penafsiran Alkitab. Hal ini membentuk sebuah kewajiban teologis bagi kita untuk memahami Alkitab sebagaimana yang Allah maksudkan melalui penafsiran akan Alkitab.

Dalam dunia penafsiran Alkitab, kewajiban teologis di atas dikenal dengan istilah eksegesis atau menafsirkan Alkitab menurut maksud originalnya (what it meant). Para penafsir menggunakan istilah penafsiran gramatikal-historis untuk proses eksegesis tersebut. Perhatikan penandasan William B. Tolar mengenai eksegesis gramatikalhistoris serta kandungan kewajiban etis dan spiritualnya,

Tidak ada elemen penafsiran yang lebih penting untuk sebuah pemahaman yang akurat akan Alkitab ketimbang metode gramatikal-historis. Ini adalah sebuah sine qua non bagi pemahaman yang valid akan Firman Allah. Tanpa sebuah penggunaan yang jujur, hati-hati, dan intelijen akan pengetahuan gramatikal dan historis, hanya ada sedikit atau bahkan tidak ada harapan bagi sebuah penafsiran yang benar akan dokumen-dokumen yang ditulis dalam bahasa-bahasa asing dalam beberapa konteks historis kuno yang berbeda...Segala sesuatu yang kurang

${ }^{11}$ Francis A. Schaeffer, He is There and He is Not Silent, in The Complete Works of Francis A. Schaeffer: A Christian Worldview, Vol. 1 (Epub version; Wheaton, Illinois: Crossway Books, 1982), loc., $165 / 222$

12Bnd. Green, The Gospel of Luke, loc., 534/816, yang menyatakan: “...all point forward to the realization of the divine purpose in Messiah."

${ }^{13}$ Lih. Eli Zaluchu, Biblical Theology: Pembahasan Metodologi dan Pendekatan Biblikadalam Membangun Teologi PL dan Teologi PB yang Alkitabiah (Semarang: Golden Gate Publishing, 2017), 4-6. 
dari itu merupakan ketidakjujuran intelektual dan imoral secara spiritual dan tidak layak bagi pribadi yang berintegritas. ${ }^{14}$

Bagian ini hanya berorientasi pada gambaran tentang bagaimana kerangka paradigma mengenai komunikasi yang terlihat dalam proses penafsiran Alkitab.

\section{Komponen Komunikasi}

Sampai sekarang, para penafsir Alkitab, ketika berbicara mengenai hubungan komunikasi dan penafsiran Alkitab, umumnya merujuk kepada teori komunikasi dari Roman Jakobson sebagai titik berangkatnya. Jakobson adalah Profesor linguistik dan sastra serta penggagas struktur linguistik. Jakobson menyebutkan tiga komponen komunikasi yang harus ada dalam setiap tindakan komunikasi verbal, dalam sebuah kalimat singkat: "the addresser sends a message to the addressee."15 (komunikator menyampaikan sebuah pesan kepada komunikan).

Pada rumusan sederhana dari Jakobson di atas, kita mendapati ada tiga komponen utama dalam sebuah proses atau tindakan komunikasi verbal, yaitu: a) komunikator, yaitu orang yang menginisiasi komunikasi; b) isi komunikasi, yaitu pesan atau informasi yang hendak dikomunikasikan oleh komunikator; dan c) komunikan, yaitu pihak yang kepadanya pesan atau informasi tersebut ditujukan - kita bisa menyebutnya penerima informasi atau pesan.

Selanjutnya, Jakobson menyatakan bahwa supaya pesan atau informasi (message) yang hendak dikomunikasikan itu bermakna maka diperlukan: konteks (context). ${ }^{16}$ Konteks di sini merujuk kepada: simbol (symbol), arti/makna (sense), dan rujukan (referent). Untuk menggambarkan maksud Jakobson tersebut, sebuah contoh dari Darrell L. Bock tentang kata "parakletos" (bnd. Yoh. 14-16) dapat digunakan. ${ }^{17}$

\begin{tabular}{ccc} 
Simbol & Arti & Rujukan \\
\hline$p-a-r-a-k-l-e-t-o-s$ & Penghibur atau Pembela & Roh Kudus \\
\hline
\end{tabular}

Dengan konteks seperti di atas, orang tidak dapat memahami pesan Yohanes yang menggunakan kata "parakletos" (pasal 14-16), jika salah satu komponen dari konteks tersebut tidak mendapat perhatian. Misalnya, jika seseorang hanya memeriksa arti kata "parakletos" dalam Kamus Bahasa Yunani (leksikon), maka hanya akan mendapati arti: "Penghibur" atau "Pembela". Namun, ini belum mewakili keseluruhan maksud Yohanes

\footnotetext{
${ }^{14}$ William B. Tolar, "The Grammatical-Historical Method," in Bruce Corley, Steve W. Lemke, and Grant I. Lovejoy (eds.), Biblical Hermeneutics: A Comprehensive Introduction to Interpreting Scripture (2nd ed.; Nashville, Tennessee: B\&H, 2002), 21.

15 Roman Jakobson, "Closing Statement: Linguistic and Poetics," in T.A. Sebeok (ed.), Style in Language (New York: Wiley; Cambridge, Mass.: MIT Press, 1960), 535.

16 Jakobson, “Closing Statement: Linguistic and Poetics," 535.

17 Bnd. Darrell L. Bock, "Single Meaning, Multiple Context and Referents: The New Testament's Legitimate, Accurate, and Multifaceted Use of the Old," in Three Views on the New Testament Use of the Old Testament, 113.
} 
karena ia menggunakan kata tersebut untuk berbicara mengenai Roh Kudus (referent). Dengan memperhatikan ketiga komponen konteks tersebut, kita memahami bahwa Roh Kudus dibicarakan oleh Yohanes dengan fungsi sebagai Penghibur dan Pembela bagi para murid yang akan ditinggalkan oleh Yesus yang nantinya naik ke sorga. ${ }^{18}$

Komponen-komponen komunikasi yang digunakan Jakobson dapat digambarkan dalam bagan berikut:

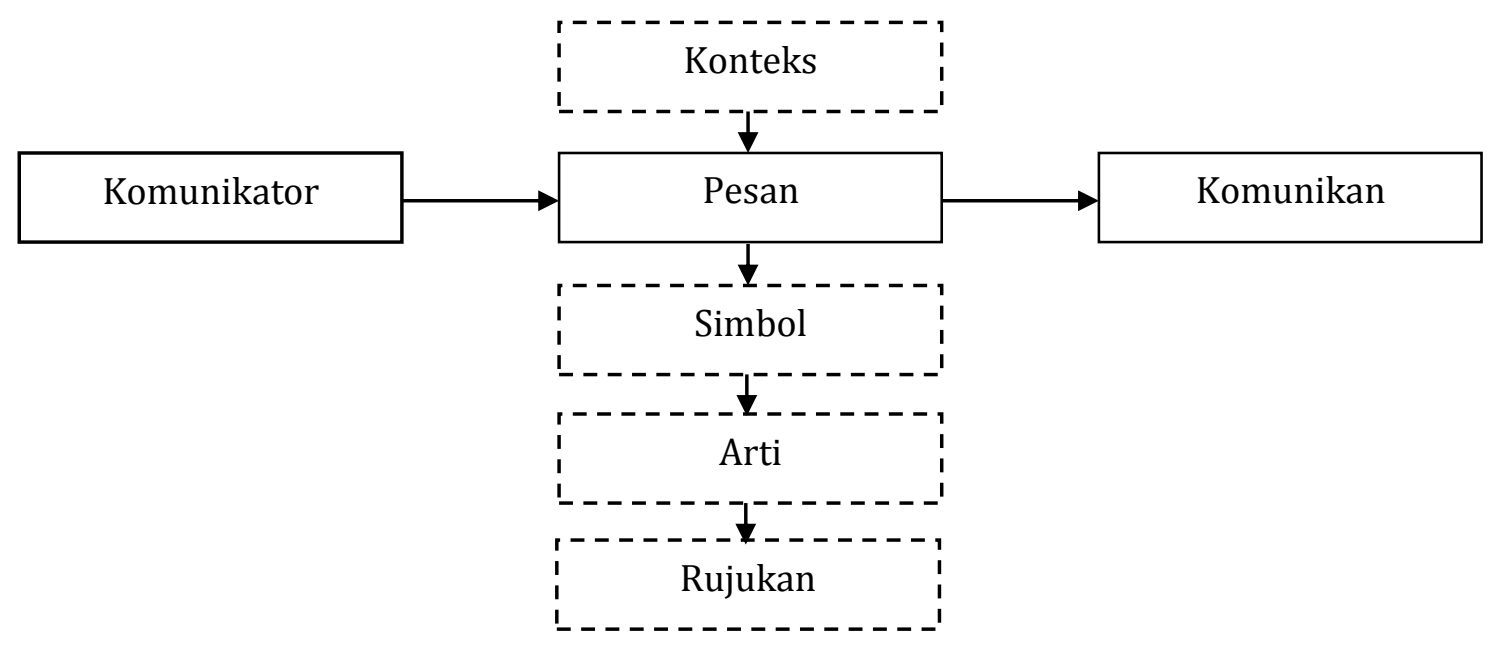

Dengan gambaran mengenai komponen-komponen komunikasi di atas, maka komponen-komponen tersebut dapat "diterjemahkan" ke dalam paradigma komunikasi penafsiran Alkitab dalam bentuk bagan sederhana, sebagai berikut:

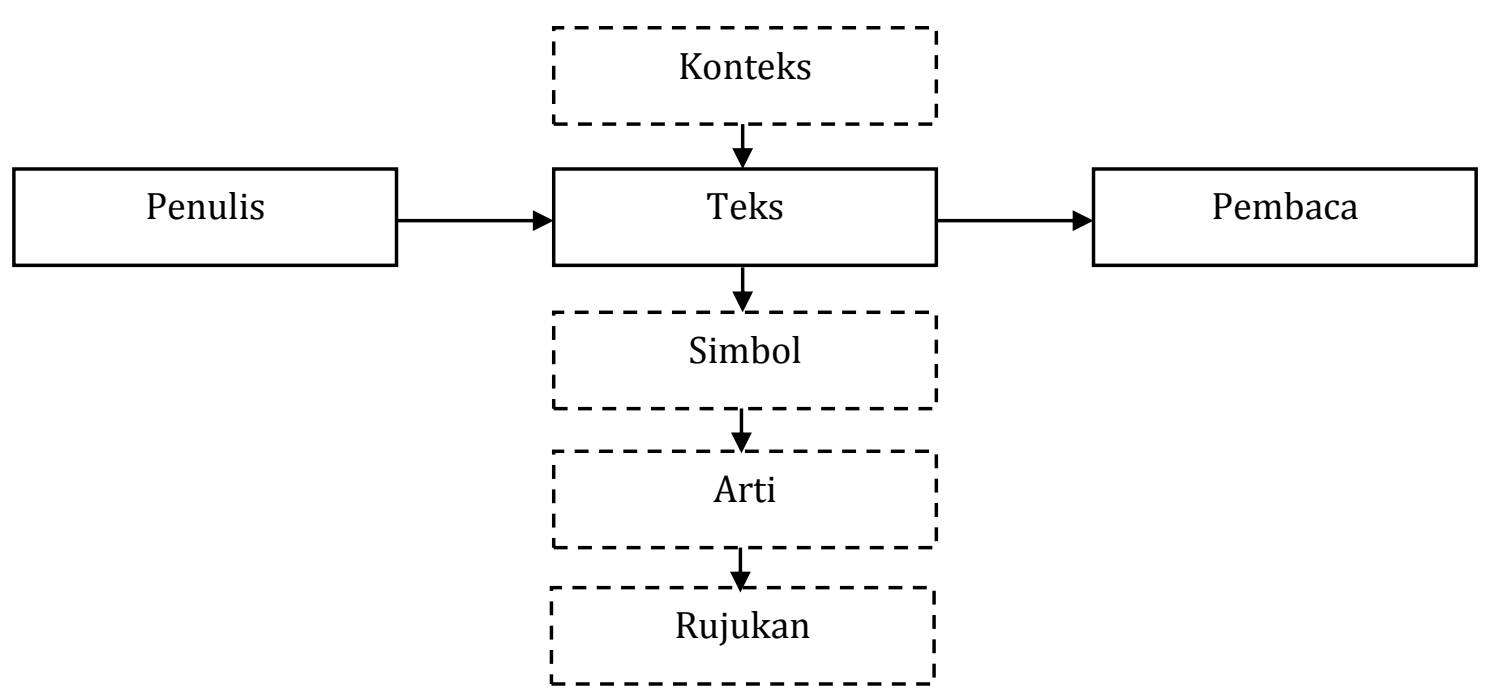

Penulis Alkitab adalah komunikator yang hendak menyampaikan pesan tertentu kepada para pembacanya. Pesan itu disampaikan melalui teks-teks Alkitab. Agar para pembaca, baik pembaca pertama maupun orang percaya saat ini, dapat memahami

${ }^{18}$ Lih. Herman Ridderbos, The Gospel of John: A Theological Commentary, trans. John Vriend (Grand Rapids, Michigan: Eerdmans, 1997), 499-500. 
pesan itu secara akurat (bnd. 2Tim. 2:15), teks-teks Alkitab harus dibaca di dalam konteks originalnya. Proses komunikasi tersebut secara keseluruhan dapat mencapai tujuannya melalui tindakan penafsiran (eksegesis) dan juga eksposisi. Melaluinya terjadi komunikasi dua arah antara Allah dan Manusia. ${ }^{19}$

\section{Makna dan Signifikansi}

Sebelum mendiskusikan mengenai locus makna pada bagian berikutnya, perlu memahami sebuah basic knowledge, di mana dalam pandangan tradisional, dibedakan antara "makna teks" (meaning) dan "signfikansi" (significane). Makna teks adalah pesan penulis di dalam teks untuk pembaca original dari teks-teks Alkitab. Artinya, makna teks yang dimaksud di sini bersifat historis atau yang dalam bahasa Inggris disebut what it meant - apa yang dimaksudkan penulis teks Alkitab bagi pembaca pertamanya saat itu. Untuk menemukan atau mengetahui makna teks (what it meant) maka para pembaca Alkitab wajib melakukan eksegesis, yang secara literal bermakna menggali keluar arti dari dalam teks.

Selanjutnya, signifikansi (significance) adalah aplikasi atau implikasi dari makna teks di atas bagi para pembaca masa kini. Untuk menemukan signifikansinya, orang melakukan tahap penafsiran yang disebut dengan eksposisi. Eksposisi bisa berupa khotbah, pengajaran, atau devosi. Dalam kategori terakhir, signifikansi bisa berubahubah sesuai dengan konteks pembaca masa kini dan bisa lebih dari satu signifikansi. Istilah teknis yang digunakan untuk gagasan ini adalah polivalensi (polyvalence).

J.E. Hirsch, Jr. menggambarkan perbedaan "makna teks" dan "signifikansi":

Makna adalah apa yang terdapat di dalam teks; sesuatu yang dimaksudkan penulis pada masa itu dengan menggunakan kata-kata atau kalimat-kalimat tertentu. Signifikansi, di sisi lain, adalah hubungan antara makna teks dengan orang, atau konsep, atau situasi, yang dihadapi pembacanya. ${ }^{20}$

Dengan kerangka komponen-komponen komunikasi tersebut maka maksud penulis dapat diidentifikasi dengan membaca teks sambil memperhatikan konteks originalnya (konteks historisnya). Atau, dapat juga memperhatikan penggunaan kata atau kalimat sesuai dengan aturan-aturan kebahasaan dengan memperhatikan tiga komponen konteks di atas, yaitu simbol, arti, dan rujukan.

Tindakan menafsir baik melalui eksegesis maupun eksposisi memaksudkan dua hal. Pertama, menghalangi rintangan komunikasi yaitu jarak sejarah, jarak budaya, jarak bahasa, dan jarak filosofis antara pembaca masa kini dan teks-teks Alkitab yang telah ditulis ribuan tahun yang lalu untuk konteks pembaca yang spesifik. ${ }^{21}$ Kedua, setelah sedapat mungkin mengatasi rintangan-rintangan di atas, pembaca masa kini

\footnotetext{
${ }^{19}$ Dale Carnigie, Sukses Berkomunikasi (Jakarta: Gramedia, 2015), vii-viii.

${ }^{20}$ E.D. Hirsch, Jr., Validity in Interpretation (New Haven and London: Yale University Press, 1967), 8.

21Virkler, Hermeneutics: Principles and Processes of Biblical Interpretation, 20. Virkler menyebutnya "gap-gap hermeneutis".
} 
dapat memahami maksud penulis secara akurat sesuai dengan yang ia kemukakan dalam teks-teks Alkitab.

McCain dan Keener menjelaskan bahwa tugas seorang penafsir adalah mencoba mengurangi jumlah kesalahpahaman terhadap teks Alkitab, dan meningkatkan kemampuan memahami komunikasi tersebut. ${ }^{22}$ Memang, seperti yang dikemukakan Hirsch, dalam tugas penafsiran seringkali yang lebih utama bagi penafsir adalah signifikansi teksnya. ${ }^{23}$ Tetapi, signifikansi harus berakar dan berasal dari makna historis teksnya. Hirsch menyebutnya sebagai tugas "kesarjanaan historis." Mereka yang mengabaikan kesarjanaan historis ini bukan hanya berpotensi besar, melainkan juga, "kadang-kadang berharap mengeksploitasi kemungkinan makna historis teks yang tetap."24

\section{Pembahasan}

Pada bagian sebelumnya ditegaskan bahwa makna teks terdapat dalam kesatuan komponen penulis dan teks yang ditulisnya, bukan pada pembacanya. Pembaca tidak berhak memberikan makna kepada teks. Makna teks telah ada dalam teks sebagaimana yang dimaksudkan penulisnya. Meski demikian, akhir-akhir ini, dalam dunia penafsiran Alkitab, khususnya sejak munculnya Postmodernisme pada akhir tahun 1960-an, para pakar kembali mengajukan pertanyaan stimulatif mengenai locus (tempat atau wadah atau sumber) di mana makna teks ditemukan. ${ }^{25}$

Postmodernisme, sebagaimana didefinisikan oleh filsuf Prancis, Jean-Francois Lyotard, sebagai "penolakan terhadap metanarasi."26 Metanarasi adalah kebenaran yang bersifat tetap, universal, objektif, dan mutlak. Sebagai gantinya, Postmodernisme menerima subyektivisme dan relativisme. Karena dalam kerangka Postmodernisme segala sesuatu itu subjektif dan relatif, maka makna teks yang bersifat tetap dan hanya satu (sebagaimana poin sebelumnya) ditolak sebagai sesuatu yang tidak patut. Menurut para penafsir Postmodern, makna dari teks-teks Alkitab tidak lagi dapat ditemukan pada kesatuan penulis dan teks seperti yang dikemukakan pada poin sebelumnya. Makna teks dapat ditentukan oleh para pembaca teks-teks Alkitab tersebut.

Prinsip penafsiran Postmodern di atas biasanya disebut dengan istilah "Kritik Respons-Pembaca" (Reader-Response Criticism). Untuk mengatasi kebingungan dalam mengategorikan Kritik Respons-Pembaca ke dalam pendekatan penafsiran Modern ketimbang Postmodernisme, penulis perlu menarik perhatian para pembaca, dimulai dengan tulisan Kevin J. Vanhoozer berjudul: Adakah Makna di dalam Teks? Buku ini ditulis untuk memberikan evaluasi kritis terhadap pendekatan penafsiran

${ }^{22}$ McCain and Craic S. Keener,Understanding and Applying the Scripture, loc., 56/265.

${ }^{23}$ E.D. Hirsch, Jr., "Meaning and Significance Reinterpreted," Critical Inquiry, Vol. 11, No. 2 (December 1984): 202-203.

${ }^{24}$ Hirsch, "Meaning and Significance Reinterpreted," 203.

25Lih. John A. Dahr, "Reader Response-Oriented," in Stanley E. Porter (ed.), Dictionary of Biblical Criticism and Interpretation (London \& New York: Routledge, 2007), 309-310.

26Jean-Francois Lyotard, The Postmodern Condition: A Report on Knowledge, trans. Geoff Bennington and Brian Massumi (Minneapolis, Minnesota: University of Minnesota Press, 1984), xxiv. 
Postmodernisme, seperti pengakuan Vanhoozer sendiri: "Buku ini menjawab tantangan 'postmodern' terhadap otoritas dan penafsiran."27 Vanhoozer menggunakan tiga sebutan metaforik untuk membedakan karakteristik penafsiran Alkitab secara tradisional, modern, dan postmodern. Ia menggunakan sebutan "zaman penulis" untuk penafsiran tradisional, "zaman teks" untuk pendekatan Modern, dan "zaman pembaca" untuk pendekatan Postmodern. Di dalam konteks "zaman pembaca" inilah, Vanhoozer mendiskusikan mengenai Kritik Respons-Pembaca, demikian:

Para kritikus respons-pembaca yang 'konservatif' mengamati bagaimana cara teks itu sendiri mengundang para pembaca untuk berpartisipasi di dalam pembentukan maknanya; teks meninggalkan ruang-ruang kosong dan hal-hal yang tidak menentu untuk di isi oleh pembaca, sehingga pembacaan menjadi semacam latihan mengisi titik-titik kosong. Mereka juga mengamati bahwa kita selalu membaca dari dalam sebuah tradisi, yaitu dari dalam suatu perangkat prasangka-prasangka sosial dan kultural yang membatasi. Para pembaca mau tidak mau harus membaca dari perspektif atau 'cakrawala' ini. Di dalam pandangan ini, makna adalah produk dari interaksi antara teks dan pembaca (yaitu 'dua cakrawala'). Para kritikus responspembaca yang 'radikal,' di sisi yang lain cenderung memberikan inisiatif kepada para pembaca untuk menaruh pertanyaan ke dalam teks atau menggunakan teks hanya untuk tujuan-tujuan dan sasaran-sasaran mereka sendiri; sebuah teks hanya sekadar menjadi sebuah kesempatan bagi pembaca untuk mengejar agendanya sendiri. Dalam pandangan ini teksnya pasif dan pembaca yang menghasilkan makna. Hal yang membedakan kedua aliran kritik respons-pembaca adalah kritikus yang radikal (biasanya merupakan penganut hermeneutika non-realisme) menolak bahwa penafsiran harus dibatasi oleh teks. ${ }^{28}$

Selain itu, Terence G. Keegan menyatakan bahwa baik Dekonstruksi maupun Kritik Respons-Pembaca merupakan bagian dari pendekatan-pendekatan Postmodern yang memberikan tantangan serius terhadap penafsiran Alkitab. ${ }^{29}$ Keegan bahkan menggunakan ekspresi, semisal: "There are examples of Postmodern reader-oriented biblical criticism."30 Demikian juga Robert Fowler yang menerapkan Kritik ResponsPembaca untuk menganalisis isi Injil Markus. Fowler percaya bahwa Kritik ResponsPembaca merupakan bagian dari cara pembacaan Postmodernisme terhadap Alkitab. ${ }^{31}$ Jadi, penulis tidak melihat alasan meyakinkan untuk menolak Kritik Respons-Pembaca dimasukkan ke dalam kategori pendekatan Postmodernisme.

Menurut cara pembacaan di atas, pembacalah yang menentukan pemaknaan terhadap Alkitab. Dan karena itu pula, makna Alkitab tidak bersifat tetap dan tidak

\footnotetext{
${ }^{27}$ Kevin J. Vanhoozer, Adakah Makna di dalamTeks? Alkitab, Pembaca, dan Moralitas Pengetahuan Sastra, terj. Jadi S. Lima (Surabaya: Momentum, 2013), 2.

${ }^{28}$ Ibid., 38-39.

${ }^{29}$ Terence G. Keegan, "Biblical Criticism and the Challenge of Postmodernism," Biblical Interpretation: A Journal of Contemporary Approaches 3 (March 1995): 1-2, 4-6.

30 Ibid., 6-7.

${ }^{31}$ Robert Fowler, Let the Reader Understand: Reader Response-Criticism and the Gospel of Mark (Harrisburg, Pennsylvania: Trinity Press International, 1996).
} 
hanya ada satu makna saja. Makna Alkitab bisa berubah-ubah sesuai situasi dan pemahaman pembacanya dan bahwa teks-teks Alkitab dapat memiliki lebih dari satu makna. Salah seorang tokoh utamanya, Stanley Fish, menyatakan bahwa tindakan menafsir teks tidak dilakukan untuk mendapatkan makna, tetapi justru memberi makna. ${ }^{32}$ Dalam kategori ini, tindakan menafsir dapat disamakan dengan tindakan menulis teks. Ia bahkan menganggap bahwa inilah yang dilakukan oleh Agustinus. Agustinus tidak membaca Alkitab untuk mendapatkan ajaran-ajaran, tetapi ia melakukannya karena ia telah meyakini terlebih dahulu akan kasih Allah sebagai hal yang akan ia temukan. Agustinus tidak dibentuk oleh teks. Agustinuslah yang menulis atau membentuk teks itu sendiri. ${ }^{33}$

Kalau memang makna teks dapat ditentukan oleh pembaca, bagaimana jika pemaknaan terhadap teks, misalnya, antara penafsir A dan penafsir B bertentangan satu sama lain? Penafsirana siapa yang harus diterima? Contoh konkretnya, teks-teks yang berkisah tentang Yesus melakukan mujizat-mujizat akan sangat berbeda tafsirannya bagi dua orang penafsir, dimana seorang berasal dari tradisi Liberal dan yang seorang lagi berasal dari tradisi Injili. Bagi penafsir dari tradisi Liberal, kisah-kisah mukjizat tersebut hanyalah mitos karena tidak ilmiah, sedangkan bagi si penafsir dari tradisi Injili akan memahaminya sebagai bukti bahwa Yesus adalah Tuhan yang Mahakuasa. Tafsiran yang manakah yang benar jika ada konflik pemaknaan seperti ini?

Untuk mengantisipasi keberatan seperti di atas, para tokoh penafsir Postmodern menyatakan bahwa kita menafsirkan Alkitab bukan untuk tujuan konsistensi. Fish menyebutnya sebagai pembacaan demonstratif (demonstrative), yaitu pembacaan demi konsistensi karena mengasumsikan kebenaran yang universal, objektif, dan mutlak. Ingat bahwa sebagai seorang Postmodernis, Fish menolak kategori-kategori ini. Bagi Fish, membaca teks dimaksudkan untuk maksud persuasif yaitu membujuk pihak lain melihat dan memahami perspektif kita terhadap teks. ${ }^{34}$

Kritik Respons-Pembaca tidak bermanfaat bagi pertumbuhan spiritual dalam komitmen terhadap proses pengudusan (progressive sanctification). Pembentukan spiritualitas dalam bentuk pengenalan akan Allah melalui pengenalan akan isi Alkitab menjadi neraca tanpa bobot di atas dacin pendekatan ini. Ada baiknya pokok di atas ditempatkan dalam konteks tugas khotbah ekspositoris yang merupakan sarana pengajaran Alkitab yang harus dan rutin di Gereja. Khotbah ekspositoris harus melibatkan eksegesis dan eksposisi. ${ }^{35}$ Karena melalui khotbah ekspositoris, pesan Firman Tuhan diperdengarkan berdasarkan makna historisnya.

\footnotetext{
32 Stanley Fish, Is There a Text in This Class? (Cambridge: Harvard University, 1980), 13-14.

${ }^{33}$ Lih. Scott Saye, "The Wild and Crooked Tree: Barth, Fish, and Interpretive Communities," in Modern Theology 12:4 (Oktober, 1996), 440-441.

${ }^{34}$ Fish, Is There a Text in This Class?, 365.

${ }^{35}$ Haddon W. Robbinson, "Homiletics and Hermeneutics," in Scott M. Gibson (ed.), Making a Difference in Preaching (Grand Rapids, Michigan: Baker, 1999), 69.
} 
David S. Dockery menegas-kan bahwa melalui khotbah ekspositoris, pengakuan akan Alkitab sebagai Firman Allah yang hidup mendapatkan pemenuhannya. Khotbah ekspositoris mempresentasikan Alkitab yang ditulis dalam konteks kuno itu berbicara kepada audiens kontemporernya atas dasar eksegesis. ${ }^{36}$ Presuposisi teologis, salah satunya, yang paling utama dari khotbah ekspostoris, bahwa pertumbuhan spiritual yang sejati dan otentik hanya dapat terjadi melalui khotbah yang setia dan akurat terhadap isi Alkitab. Itulah sebabnya, bagi Paulus, criteria kelayakan seorang pemberita firman adalah akurasi dan ketepatan penjelasan firmankebenaran (2 Tim. 2:15).

\section{Kesimpulan}

Kerangka komponen-komponen komunikasi seperti makna teks (meaning) terdapat dalam kesatuan penulis dan teks. sebagaimana yang telah didefinisikan oleh Hirsch yang membedakannya dari signfikansi teks. Pembacaan teks Alkitab yang diusulkan oleh Postmodernisme (Kritik Respons-Pembaca) merupakan teori yang tidak logis, dan berbahaya. Teori Kritik Respons-Pembaca tidak logis karena memiliki standar ganda; di satu sisi para pengusung teori ini, ketika menulis buku, berharap agar buku-buku mereka dibaca dan dimengerti sebagaimana yang mereka maksudkan melalui konstruksi kata-kata dan kalimat-kalimat dalam buku-buku mereka, dan di sisi lain mereka membolehkan pembaca Alkitab memberikan arti atau makna kepada teks-teks Alkitab yang dibaca. Setiap "pesan" atau "informasi" atau "makna" harus dimengerti sebagaimana yang dimaksudkan oleh komunikatornya. Anda tidak dapat mengartikan pesan atau informasi atau makna itu sesuai yang Anda inginkan. Dengan kata lain, Kritik Respons-Pembaca merupakan sebuah distorsi terhadap proses komunikasi yang sehat dan bermakna.

\section{Referensi}

Bavinck,Herman,ReformedDogmatics: Vol One - Prolegomena, trans. John Vriend. Epub version; Grand Rapids, Michigan: Eerdmans, 2003.

Bavinck,Herman,ReformedDogmatics: Volume Two - God and Creation, trans. John Vriend. Epub version; Grand Rapids, Michigan: Eerdmans, 2014.

Beale,Greg K.,BukuPeganganPenggunaanPerjanjian Lama oleh PerjanjianBaru, terj. Lena S. Tjandra. Malang: SAAT, 2015.

Blue,Scott A., "The Hermeneutics of E.D. Hirsch, Jr. and Its Impact on Exspository Preaching: Friend of Foe?," Journal of Evangelical Theological Society 44/2. June 2001.

Bock,DarrellL.,Luke 9:51 - 24:53. Epub version; BECNT; Grand Rapids, Michigan: Baker Academic, 1996.

Dahr,John A., "Reader Response-Oriented," in Stanley E. Porter, ed., Dictionary of Biblical Criticism and Interpretation. London \& New York: Routledge, 2007.

Danesi,Marcel,Dictionary of Media and Communications. New York, London: M.E. Sharpe, 2009.

${ }^{36}$ David S. Dockery, "Preaching and Hermeneutics," in Michael Duduit (ed.), Handbook of Contemporary Preaching (Nashville, Tennessee: B\&H, 1992), 142. 
Dockery,David S., "Preaching and Hermeneutics," in Michael Duduit, ed., Handbook of Contemporary Preaching (Nashville, Tennessee: B\&H, 1992.

Enns,Peter,Inspiration and Incarnation: Evangelicals and the Problem of the Old Testament. Grand Rapids, Michigan: Baker Academic, 2005.

Fee, Gordon D., dan Douglas Stuart, Hermeneutik: BagaimanaMenafsirkanFirmanTuhandenganTepat!Malang: Gandum Mas, 2006.

Fish,Stanley,Is There a Text in This Class? Cambridge: Harvard University, 1980.

Frame,JohnM.,Systematic Theology: An Introduction to Christian Belief. Epub version; Phillipsburg, New Jersey: P\&R, 2013.

Green,JoelB.,The Gospel of Luke.Epub version; NICNT; Grand Rapids, Michigan: Eerdmans, 1977.

Gundry,Stanley N., ed., Three Views on the New Testament Use of the Old Testament. Grand Rapids, Michigan: Zondervan, 2007.

Helm,Paul, "John Calvin: The SensusDivinitatis and the Noetics Effects of Sin," International Journal for Philosophy of Religion, 43/2. 1988.

Hirsch,E.D., Jr., "Meaning and Significance Reinterpreted," Critical Inquiry, Vol. 11, No. 2. December 1984.

Hirsch,E.D., Jr., Validity in Interpretation. New Haven and London: Yale University Press, 1967.

Jakobson,Roman, “Closing Statement: Linguistic and Poetics," in T.A. Sebeok, ed., Style in Language. New York: Wiley; Cambridge, Mass.: MIT Press, 1960.

Longman,Tremper,Psalms. Epub version; TOTC Vols. 15-16; Downers Grove, Illinois:IVP, 2014.

Lyotard,Jean-Francois, The Postmodern Condition: A Report on Knowledge, trans. Geoff Bennington and Brian Massumi. Minneapolis, Minnesota: University of Minnesota Press, 1984.

McCain,Danny, and Craic S. Keener,Understanding and Applying the Scripture. Epub version; Plauteau State: Africa Christian Textbook, 2012.

Osborne,GrantR.,The Hermeneutical Spiral: A Comprehensive Introduction to Biblical Interpretation. Downers Grove, Illinois: IVP Academic, 2006.

Ridderbos,Herman,The Gospel of John: A Theological Commentary, trans. John Vriend. Grand Rapids, Michigan: Eerdmans, 1997.

Robbinson,Haddon W., "Homiletics and Hermeneutics," in Scott M. Gibson (ed.), Making a Difference in Preaching. Grand Rapids, Michigan: Baker, 1999.

Saye,Scott, "The Wild and Crooked Tree: Barth, Fish, and Interpretive Communities," in Modern Theology 12:4. Oktober, 1996.

Sutanto,Hasan,Hermeneutik: Prinsip-prinsip dan MetodePenafsiranAlkitab. EdisiRevisi; Malang: SAAT, 2007.

Tolar,William B., "The Grammatical-Historical Method," in Bruce Corley, Steve W. Lemke, and Grant I. Lovejoy. eds., Biblical Hermeneutics: A Comprehensive Introduction to Interpreting Scripture. $2^{\text {nd }}$ ed.; Nashville, Tennessee: B\&H, 2002.

Van Bruggen,Jakob,MembacaAlkitab: SebuahPengantar, terj. AmsyatiSusilaradeya dan Henk Venema. Surabaya: Momentum, 2009.

Virker,HenryA.,Hermeneutics: Principles and Processes of Biblical Interpretation. Grand Rapids, Michigan: Baker, 1981. 